\section{Water Intoxication in Relation to Acute Psychotic Disorder}

\section{E. R. ALEXANDER, T. J. CROW, S. M. HAMILTON}

British Medical fournal, 1973, 1, 89

Psychogenic polydipsia may present a problem in relation to the diagnosis of diabetes insipidus (Carter and Rubbins, 1947; Barlow and de Wardener, 1959). More rarely (Barahal, 1938; Bewley, 1964) polydipsia results from an acute psychiatric disturbance and is of such magnitude as to cause water intoxication (Rowntree, 1926). We here report a case in which coma and convulsions were the consequence of acute water in toxication resulting from a schizophrenic delusion.

\section{Case Report}

A man aged 31 was first referred for a psychiatric opinion in May 1969 complaining of numerous vague pains in his abdomen and chest. In August 1970 he became acutely disturbed with grandiose ideas, complaints of his "insides being poisoned," ideas of reference, and auditory hallucinations. A diagnosis of schizophenia was made and he made a good recovery on treatment with trifluoperazine.

At 1 a.m. on 5 September 1971 his general practitioner requested emergency psychiatric admission. The patient had stopped his medication some time previously, had become withdrawn, and had spent most of the previous three months in bed. For some 12 hours before admission he had been aggressive towards his wife and family, complaining of abdominal pain, and had been drinking quantities of water.

The patient arrived unaccompanied and was co-operative and fully orientated on admission. A few minutes later he was found slumped in a chair, his speech was slurred, he was confused, and he had been incontinent of urine. There was no previous history of epilepsy. He vomited a large amount of clear fluid and was incontinent of two foul-smelling loose stools. Over the course of the next few hours he sank into coma and showed periodic bilateral tonic and clonic spasms. On transfer to the medical ward he was found to respond only to painful stimuli. On several occasions he vomited clear fluid. Respiratory rate and volume were adequate. The pupils were dilated, with an equal but sluggish response to light, and muscle tone was noticeably increased. A fine tremor was present in all limbs, which were in the "decerebrate" position, and there were occasional athetoid movements of both upper limbs. All deep tendon reflexes were increased equally and the plantar reflexes were flexor. Intermittent facial twitching and suffusion suggested continuing seizures.

A visit to his wife disclosed the extent of his water drinking on the previous day, and a diagnosis of acute water intoxication was confirmed (see table). Twelve hours after admission to the medical ward there had been no improvement, and a slow intravenous infusion of hypertonic (5\%) saline was started at a rate of about $50 \mathrm{ml} / \mathrm{hr}$, a total of $250 \mathrm{ml}$ being given. Over 61. of urine of specific gravity 1.000 was passed between admission and the end of the infusion.

The infusion of hypertonic saline produced a very noticeable improvement in the patient's level of consciousness, and after 250

\section{Ross Clinic, Aberdeen AB9 2ZX}

E. R ALEXANDER, D.P.M., M.R.C.PSYCH., Senior Psychiatric Registrar T. J. CROW, M.R.C.P., M.R.C.PSYCH., Lecturer in Mental Health

Woodend Hospital, Aberdeen

S. M. HAMILTON, M.R.C.P., Medical Registrar
Estimations of Serum Electrolytes and Serum and Urine Osmolality

\begin{tabular}{|c|c|c|c|c|c|c|c|}
\hline & \multicolumn{7}{|c|}{ Serum Estimations on: } \\
\hline & \multicolumn{4}{|c|}{$5 / 9 / 71$} & \multirow{2}{*}{$6 / 9 / 71$} & \multirow{2}{*}{$-\frac{7 / 9 / 71}{9 \text { a.m. }}$} & \multirow{2}{*}{$8 / 9 / 71$} \\
\hline & 9 a.m. & 1 p.m. & 6 p.m.* & 11 p.m. ${ }^{*}$ & & & \\
\hline 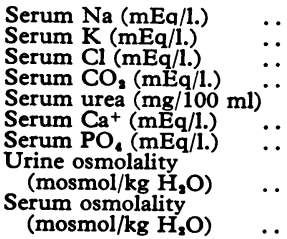 & $\begin{array}{c}120 \\
3.6 \\
90 \\
22.5 \\
27 \\
3.8 \\
1.3 \\
- \\
-\end{array}$ & $\begin{array}{c}120 \\
3.9 \\
88 \\
21.5 \\
26 \\
3.8 \\
1.1 \\
250\end{array}$ & $\begin{array}{c}120 \\
4 \cdot 4 \\
90 \\
22 \cdot 0 \\
24 \\
= \\
- \\
-\end{array}$ & 274 & $\begin{array}{c}138 \\
3 \cdot 6 \\
105 \\
20 \cdot 0 \\
40 \\
708 \\
-\end{array}$ & $\begin{array}{c}139 \\
3 \cdot 6 \\
107 \\
24 \cdot 0 \\
54 \\
= \\
-\end{array}$ & $\begin{array}{c}141 \\
3.9 \\
109 \\
21 \cdot 5 \\
35 \\
= \\
-\end{array}$ \\
\hline
\end{tabular}

Intravenous infusion of $250 \mathrm{ml}$ hypertonic ( $5 \%$ ) saline was begun at 6 p.m. on 5/9/7 and completed at 11 p.m.

$\mathrm{ml}$ had been given he could easily be roused and responded to his name. Thirty-six hours later he was fully conscious but withdrawn and uncommunicative. On transfer to psychiatric care it emerged that he was suffering from the delusion that a parasitic worm inhabited his abdomen and wandered from there into his chest. $\mathrm{He}$ remembered drinking large amounts of water before admission and stated that he had thought this would "flush out his system." $\mathrm{He}$ was treated with fluphenazine and was discharged on 22 October showing no psychiatric symptoms. He remained well and was working three months after discharge.

\section{Comment}

The diagnosis of water intoxication rests on the findings of a low serum sodium and plasma osmolality (Barlow and de Wardener, 1959). Water intoxication from increased intake can be differentiated from that due to inappropriate antidiuretic hormone secretion by the fact that the specific gravity of the urine is below 1.002-1.003 in the former case.

The psychological reasons for compulsive water drinking are often obscure. Cases have been reported in which the polydipsia was closely associated with affective episodes of a depressive (Barlow and de Wardener, 1959) or hypomanic type (Dingman et al., 1957), and in other cases there have been longstanding "hysterical" personality traits (Barlow and de Wardener, 1959). Of seven cases reported in the literature (Barahal, 1938; Swanson and Iseri, 1958; Carter, 1959; Emery, 1959; Bewley, 1964 (2 cases); and the present case) of self-induced water intoxication proceeding to coma, in three cases the patient suffered from schizophrenia and in each of the others there was a history of chronic alcoholism. Thus it may be possible on psychiatric grounds to differentiate these cases from the more commonly occurring syndrome of chronic psychogenic polydipsia.

The response in this case to intravenous hypertonic saline was rapid. The fact that some patients (Barahal, 1938; Bewley, 1964) have remained unconscious for several days without such treatment suggests that this form of management should be adopted as soon as the diagnosis has been made.

\section{References}

Barahal, H. S. (1938). Psychiatric Quarterly, 12, 767.

Barlow, E. D., and de Wardener, H. E. (1959). Quarterly fournal of Medicine, 28, 235.

Bewley, T. H. (1964). British Medical fournal, 3, 864.

Carter, A. C., and Robins, J. (1947). Fournal of Clinical Endocrinology, 7, 753.

Carter, T. J. (1959). British Medical fournal, 2, 367.

Dingman, J. F., Benirschke, K., and Thorn, G. W. (1957). American fournal of Medicine, 23, 226.

fournal of Medicine, 23, 226.
Emery, R. (1959). British Medical fournal, 2, 190.

Rowntree, L. G. (1926). Fournal of Pharmacology and Experimental Therapeutics, 29, 135.

Swanson, A. G., and Iseri, O. A. (1958). New England fournal of Medicine, 258, 831 . 